\title{
Literasi.co sebagai Media Alternatif dan Kooperasi Akar Rumput
}

\author{
Eni Maryani ${ }^{1}$ dan Justito Adiprasetio ${ }^{2}$ \\ ${ }^{1,2}$ Universitas Padjadjaran
}

\begin{abstract}
ABSTRAK
Pasca reformasi 1998 Literasi.co adalah salah satu media alternatif yang menjadi corong dan berusaha memberikan ruang pada isu-isu kalangan bawah atau suara akar rumput. Tujuan penelitian ini adalah mengungkap konteks dibentuknya Literasi.co dalam membangun dirinya sebagai media alternatif yang bersifat ko-operasi dan independen. Selain itu juga bertujuan untuk mengungkap upaya Literasi.co dalam membuka ruang alternative di media dan mengadvokasi beragam isu di masyarakat bawah akar rumput yang selama ini dimarjinalkan oleh agenda media arus utama. Penelitian ini menggunakan studi kasus dengan teknik pengumpulan data yang mencakup wawancara mendalam, observasi, analisis isi naratif dan studi literatur. Hasil penelitian menunjukkan bahwa Literasi.co melalui penggunaan model pengelolaan bersama secara kooperatif dan berbasis pada solidaritas sosial berhasil membangun kerja keredaksian yang independen dan bersinergi dengan semangat aktivisme sosial akar rumput. Literasi.co mengangkat berbagai isu, merentang dari isu agraria, tata ruang kota, kebudayaan, hingga sastra, dan berhasil menawarkan diskursus alternatif dari dan untuk masyarakat sipil, serta menyuarakan suara akar rumput pada publik yang lebih luas. Walaupun begitu, terdapat tantangan dalam praktik keredaksian Literasi.co, yaitu keterbatasan kuantitas tulisan sehingga terjadi inkonsistensi terbitnya tulisan. Sebagai sebuah gerakan sosial, Literasi.co tidak dapat bekerja sendiri. Untuk itu direkomendasikan agar Literasi.co dapat meningkatkan jaringan kerjasamanya.
\end{abstract}

Kata-kata Kunci: Gerakan sosial; independen; kooperasi; literasi.co; media alternatif

\section{Literasi.co as Alternative Media and Grassroots Cooperative}

\begin{abstract}
Post-1998 reform Literasi.co became an alternative media that became the people's voice and offers to make sphere for lower-class issues or grassroots voices. The purpose of this study is to uncover the context of the formation of Literasi.co in establishing itself as an alternative media that is essentially co-operative and independent. In addition, it also aims to uncover Literasi.co's efforts to open alternative spaces in the media and advocates various issues that arise among grassroots communities - which have been marginalized by the mainstream media. This study uses case studies through data collection techniques that include in-depth interviews, observation, narrative content analysis and literature studies. The results of the study show that by using a cooperative co-management model based on social solidarity, Literasi.co succeeded in building independent editorial work and synergized with the spirit of grassroots social activism raises various issues, extending from agrarian issues, urban spatial planning, culture, to literature, and successfully offers alternative discourses from and for civil society, as well as voicing grassroots voices to the wider public. Even so, there are challenges in Literasi.co's editorial practice, specifically the limited number of human resources and inconsistencies in the publication of their writings. As a social movement, Literasi.co cannot work alone. For this reason, it is recommended that Literasi.co increase their network.
\end{abstract}

Keywords: Alternative media; cooperative; independent; literasi.co; social movement

Korespondensi: Dr. Eni Maryani, M.Si. Universitas Padjadjaran. J1. Raya Bandung-Sumedang KM. 21 Jatinangor, 45363.Email: eni.maryani@unpad.ac.id 


\section{PENDAHULUAN}

Reformasi pada satu sisi merupakan penanda tumbangnya otoritarianisme negara yang puluhan tahun sebelumnya merepresi pers. Reformasi yang terjadi pada tahun 1998 memberikan angin segar pada iklim demokrasi, karena regulasi yang sebelumnya sangat mengikat mulai memberi kebebasan.

Presiden Habibie melalui Menteri Penerangan Yunus Yosfiah mencabut beberapa peraturan yang dianggap membelenggu kebebasan pers. Peraturan itu di antaranya adalah Permenpen No.01/Per/ Menpen/1984 tentang Surat Ijin Usaha Penerbitan Pers (SIUPP), dan Permenpen 1969 tentang ketentuan pokok wartawan (Maryani, 2011).

Peraturan tersebut meningkatkan secara tajam pertumbuhan media di Indonesia. Hingga 1998, tahun terakhir Orde Baru berkuasa, hanya terdapat 289 media cetak, 6 stasiun televisi dan 740 radio di Indonesia. Pasca reformasi jumlah tersebut melonjak secara signifikan, hingga tahun 2008, terdapat 860 media cetak, 60 televisi dan tidak kurang dari 2000 radio ("Setiap Hari Terbit Lima Media Massa Baru Pasca-Reformasi," 2008). Kondisi pasca reformasi mengakibatkan spesialisasi media yang masif, namun ia juga melahirkan pemodal yang terpusat dan membangun konglomerasi dalam industri media; hal yang kemudian menjadi ancaman demokrasi itu sendiri (Lim, 2012; Nugroho, Putri, \& Laksmi, 2012).

Namun di tengah gempuran konglomerasi media tersebut, bermunculan praktik resistensi di lingkup akar rumput, banyak media alternatif yang dibangun untuk mengemas narasi pinggiran atau dengan tujuan tertentu. Media alternatif bermunculan untuk merebut visibilitas dari pasar media yang sesak (Kenix, 2011).

Walaupun bukan yang pertama, Literasi. co menjalankan modus ko-operatif yang sebelumnya tidak banyak dicoba oleh mediamedia lain, bahkan oleh media dengan label "alternatif" sekalipun. Akan tetapi idealisme untuk mendirikan media alternatif sebagai upaya melawan kekuasaan ekonomi politik konglomerasi media berhadapan dengan beragam tantangan terkait keberlangsungan media tersebut.

Membangun media alternatif dengan pengelolaan modal yang relatif sama dengan media arus utama tentunya akan kalah bersaing karena kekuatan modal yang sangat tidak sebanding, apalagi saat kepemilikan media arus utama semakin terkonsentrasi. Selain itu logika ekonomi politik media arus utama juga berpotensi untuk mengintervensi ruang redaksi.

Beberapa riset terdahulu yang telah dilakukan terkait media alternatif di antaranya Jalin Merapi sebagai jaringan media dan gerakan sosial penanggulangan bencana (Mahaswari, 2012), Jakartabeat sebagai media musik alternatif (Nugraha \& Santana, 2009), dan Magdalene.co (Maryani \& Adiprasetio, 2017) sebagai media advokasi perempuan. Media-media yang dikaji adalah contoh media yang dibangun dengan tujuan menciptakan narasi-narasi yang selama ini tidak diangkat oleh media arus utama.

Selain itu terdapat studi yang mengelaborasi potensi media alternatif sebagai katalis demokratisasi di daerah-daerah pasca reformasi. Media alternatif merupakan salah satu kunci utama untuk melaksanakan upaya desentralisasi politik, pasca kekuasaan Orde Baru yang sangat sentralistis (Yusuf, 2011). Sedangkan Jurriens mencoba menangkap pergulatan radio komunitas di Jawa Tengah pasca-reformasi. Segala keunikan yang dipengaruhi aspek sosial dan kebudayaannya menjadi bagian katalis kultur partisipasi, yang berarti menopang demokratisasi akar rumput (Jurriens, 2003).

Sementara menurut Adorno, media arus utama yang berkembang menjadi media komersial akhirnya juga menjadi kendala berkembangnya peradaban pada komunitas budaya dengan menghapus potensi diskusi terkait adanya perbedaan pendapat yang sebelumnya sangat populer (Babe, 2009).

Pada tahun 2012, di Indonesia telah terdapat 13 grup yang menjadi pusat konsentrasi kapital industri media: Jawa Pos Group, Mahaka Media Group, Kompas Media Group, Media Nusantara Citra Group, Bakrie \& Brothers, Visi Media Asia, Emtek Group, State Public, KM Bali Post, Trans Corps, Media Group, Lippo Group, Mugi Reka Abadi Group (Lim, 2012).

Pada tahun 2016, peta tersebut sedikit bergeser, seperti Bakrie \& Brothers telah berkurang pengaruhnya, atau terjadi penguatan pada Media Nusantara Citra Group karena juga menguasai sebagian jaringan TV Kabel. Akan tetapi perubahan-perubahan tersebut pada dasarnya tidak signifikan karena praktik konglomerasi tetap terjadi dan meniscayakan 
terjadinya konsentrasi modal. Perubahan yang terjadi hanya pergeseran aktor-aktor penguasanya.

Pada akhirnya, reformasi menjadi pedang bermata dua, ia menjadi pra-syarat terjadinya demokrasi, namun pada perkembangannya, ternyata reformasi juga memungkinkan terjadinya distorsi terhadap proses demokrasi. Konglomerasi media menciptakan berbagai akibat terhadap iklim bermedia - produksidistribusi-konsumsi dan praktik tersebut berdampak terhadap situasi demokrasi di Indonesia. Menurut Syahputra terdapat empat akibat konglomerasi media terhadap praktik media dan demokrasi di Indonesia (Syahputra, 2013). Pertama, pemberitaan menjadi tidak beragam dan tak bermutu, yang disebabkan oleh agenda efisiensi dalam sistem produksi informasi. Sebagai contoh salah satu berita yang diproduksi oleh media di satu anak perusahaan dari grup media, dapat digunakan oleh anak perusahaan lainnya dalam grup media yang sama.

Kedua, terabaikannya agenda publik, berganti menjadi agenda yang dikendalikan oleh kepentingan pemilik modal dan selera pasar. Hal tersebut dimungkinkan mengingat kuasa tertinggi ada di tangan pemegang kekuasaan atau konglomerat media.

Ketiga, masyarakat hanya berfungsi sebagai konsumen media. Hal ini membuat kemungkinan menciptakan jurnalisme yang partisipatif dan mampu menjadi alat kontrol pemerintah untuk kepentingan warganya sulit diwujudkan. Masyarakat tidak bisa mengandalkan media arus utama, mengingat kooptasi kapital membuat agenda untuk mewujudkan media sebagai (ruang) publik partisipatif menjadi suatu agenda yang tidak dimungkinkan.

Keempat, memburuknya iklim organisasi pekerja. Pekerja hanya diposisikan sebagai mesin yang bisa diganti oleh mesin yang lain. Pekerja sekadar menjadi syarat dari sistem produksi informasi bukan sebagai pekerja yang dihargai dan terkait dengan sistem tersebut. Selain itu ditemukan pula bahwa media yang tidak memiliki serikat pekerja lebih banyak dibanding media yang memiliki serikat pekerja. Di beberapa grup media, serikat pekerja bahkan secara terang-terangan dilarang (Syahputra, 2013). Kondisi tersebut mendorong pekerja di industri media menjadi semakin individualistis.
Merujuk pada akibat yang disebabkan oleh praktik konglomerasi media maka hal tersebut diasumsikan memaksa masyarakat sipil membuat agenda untuk menciptakan suatu model alternatif dalam industri media. Beragam elemen masyarakat sipil dalam berbagai isu dengan ragam komunitas menyusun agenda media masing-masing. Salah satu agenda adalah keinginan untuk menciptakan media alternatif yang mandiri, independen, mengamalkan demokrasi serta menantang konglomerasi.

Tak sedikit pemikir yang berupaya membangun teoretisasi terkait media alternatif. Berbasis teori kritis. Salah satunya menjelaskan bahwa media alternatif adalah media partisipatoris yang berarti secara financial bersifat non-komersial (Atton, 2001). Menurut Sandoval dan Fuchs, tindak partisipasi dan pencarian modus alternatif dari media harus juga dilandaskan pada konteks kapitalisme yang lebih besar (Sandoval \& Fuchs, 2010). Sementara Atton menyatakan bahwa media alternatif dapat didefinisikan sebagai media yang didedikasikan untuk 'orang-orang biasa' atau 'orang-orang yang yang dipinggirkan' atau 'tidak dipedulikan' oleh media arus utama (Wahl-Jorgensen \& Hanitzsch, 2008).

Secara kritis, konsep media alternatif mendekonstruksidefinisikomunikasimassayang ketat dengan basis keahlian (skills), kapitalisasi (capitalization), dan kontrol (controls). Ketiga aspek tersebut, menurut James Hamilton harus didekonstruksi (deprofessionalization, decapitalization, deinstitutionalization) demi membangun corak kepublikan yang selama ini hanya dianggap sebagai komoditas oleh media arus utama. Walaupun ia berjarak dari ketiga basis yang menjadi landasan dari tingkat kemapanan suatu media, media alternatif justru lebih potensial dalam merefleksikan praktikpraktik demokrasi langsung dan desentralisasi, serta jaringan solidaritas kolektif - seperti yang disebut oleh Alberto Mellucci sebagai jantung aktivisme dan gerakan sosial (Wahl-Jorgensen \& Hanitzsch, 2008).

Berdasarkan beberapa pandangan tersebut maka dapat dikatakan bahwa media alternatif dibentuk dan digunakan oleh kaum marginal dan/atau minoritas untuk menyampaikan pesan-pesan yang diperjuangkan kelompoknya. Pesan-pesan yang kerap kali tidak terakomodir oleh pemerintah maupun media arus utama.

Media alternatif juga dapat dikatakan 
merupakan instrumen perlawanan terhadap dominasi media arus utama yang telah dikooptasi oleh kekuatan ekonomi politik. Salah satunya adalah dalam bentuk Jurnalisme warga, dengan kepemilikan yang dikelola secara kolektif dan mandiri, memiliki jalur distribusi alternatif dan bersikap kritis. Karakteristik tersebut menjadi kualitas-kualitas yang dimiliki oleh media alternatif dan diharapkan dapat menciptakan demokratisasi masyarakat (Fuchs, 2008). Media alternatif harus berlandaskan pada visi untuk menciptakan masyarakat demokratis tanpa represi dan opresi, di mana kekuatan paling mendasarnya adalah partisipasi akar rumput (Sandoval \& Fuchs, 2010). Media alternatif harus dapat dilihat sebagai bentuk dari ruang publik tandingan (Fuchs, 2010).

Pada era sekarang, media digital tampaknya menjadi platform yang banyak digunakan oleh media alternatif. Hal ini dikarenakan luasnya cakupan yang mungkin dijangkau oleh media digital, selain juga karena rendahnya biaya yang harus dikeluarkan untuk platform tersebut. Merujuk pada beberapa alasan tersebut maka dapat diasumsikan keberadaan Literasi.co merupakan salah satu cara mengembangkan media alternatif berbasis platform media digital.

Akan tetapi walaupun media digital berpotensi untuk menjadi media alternatif yang dapat memfasilitasi apa yang disebut dengan aktivisme digital, penggunaannya bukan tanpa kendala. Lim menyatakan bahwa partisipasi di media digital tidak serta merta terwujud pula dalam kehidupan nyata (Lim, 2013).

Sebagai media alternatif maka salah satu hal yang mendasar, umumnya media tersebut ingin memperjuangkan perubahan dengan menggunakan media. Salah seorang aktivis gerakan sosial Topatimasang menyatakan bahwa perubahan sosial sesungguhnya bukan hanya soal mengganti rezim kekuasaan politik dan ekonomi, melainkan juga soal keberanian dan ketegaran mempertahankan ruang dan caracara kehidupan yang mampu membendung segala bentuk kekuasaan (Crawshaw \& Jackson, 2015).

Merujuk pada pernyataan tersebut maka Literasi.co bertujuan mempertahankan ruang bagi suara akar rumput sebagai respons pada kekuasaan para pemilik media yang memarginalkan isu-isu akar rumput. Hal itu juga yang mendasari dibentuknya Literasi. co yang kemudian menjadikan jurnalisme advokasi sebagai salah satu aktivitas utamanya. Pertanyaannya adalah bagaimana hal tersebut dilakukan?.

Sejalan apa yang diupayakan Literasi.co, Silvio Waisbord (Wahl-Jorgensen \& Hanitzsch, 2008), menyatakan bahwa jurnalisme advokasi pada akhirnya, sangat bergantung pada konteks di mana ia diterapkan. Jurnalisme advokasi adalah bentuk dari "mobilisasi politik untuk meningkatkan kekuatan individu maupun kelompok, dan untuk menciptakan suatu institusi yang lebih responsif terhadap kebutuhan manusia." Dalam penelitian ini Literasi.co ditempatkan sebagai media yang berupaya melakukan mobilisasi politik untuk mengoptimalkan kekuatan masyarakat. Pada derajat tertentu media alternatif sangat mungkin berbalik, memengaruhi media arus utama (Lin, 2016). Upaya tersebut terkait dengan berkembangnya teknologi media digital dan kemampuan publik dalam mengakses media melalui literasi, walaupun era ini juga punya tantangan dari kacamata etika (Yudha, 2017).

Meningkatnya penggunaan media digital oleh publik menjadi modal untuk mengembangkan sikap independen melalui media digital. Akan tetapi sikap media yang independen bagi pendiri Literasi.co hanya dimungkinkan melalui model kerja yang kooperasi: 'berbareng, bergerak'. Kooperasi adalah prinsip moralitas tertinggi: fondasi dari etika intersubjektif dan objektif, etika kooperatif (Sandoval \& Fuchs, 2010). Terkait dengan model kerja tersebut maka upaya apa yang dilakukan dan tantangan seperti apa yang dihadapi Literasi.co terutama untuk memperjuangkan suara atau kepentingan akar rumput dan media yang demokratis?.

Menurut Tracy kemandirian di sektor media menjadikan media lebih demokratis dan menjadi fondasi terciptanya demokrasi pada skala yang lebih besar (Tracy, 2013). Media digital menjadi bagian penting dalam proses demokrasi, seperti yang terjadi dalam Pemilihan Presiden 2014 di Indonesia. Tim sukses Jokowi mengakui bahwa media sosial berbasis digital merupakan salah satu strategi komunikasi yang efektif (Senova, 2016).

Berdasarkan kajian terdahulu, teori dan konsep-konsep yang dirujuk serta pertanyaan yang muncul maka penelitian ini bertujuan untuk mengungkap konteks terbentuknya Literasi.co dalam membangun serta mengelola 
dirinya sebagai media alternatif yang bersifat kooperasi dan independen. Selain itu penelitian ini juga bertujuan mengungkap upaya Literasi. co membuka ruang alternatif di media dan mengadvokasi beragam isu di masyarakat bawah -akar rumput- yang selama ini dimarjinalkan oleh agenda media arus utama.

\section{METODE PENELITIAN}

Penelitian ini menggunakan metode kualitatif dengan pendekatan studi kasus terhadap sebuah media online bernama Literasi.co. Pada awalnya penelitian kualitatif berkembang dalam penelitian lapangan akan tetapi pada akhir menurut Tracy penelitian kualitatif semakin sering digunakan untuk mempelajari konteks virtual dan mediasi (Tracy, 2013). Merujuk pada pandangan Tracy, maka penelitian tentang Literasi.co merupakan penelitian kualitatif yang memiliki konteks virtual.

Berdasarkan kebutuhan data dalam penelitian ini maka untuk teknik pengumpulan data digunakan beberapa teknik, yaitu observasi, wawancara, analisis isi dan studi literatur. Observasi dilakukan dengan mengamati aktivisme para individu yang terlibat dan praktik pengelolaan media digital terkait dengan mekanisme dan sistem produksi maupun konsumsi dalam praktik Literasi.co.

Wawancara dilakukan terhadap empat orang terdiri dari pendiri dan pengelola dan pembaca yang juga penulis di Literasi.co. Terhadap pendiri, wawancara dilakukan untuk mendapatkan data terkait dengan latar belakang pendirian dan idealisme yang mendasarinya serta berbagai tantangan yang dihadapi. Selain itu dari pengelola dan pembaca yang juga penulis khususnya dikumpulkan beragam data tentang pengelolaan dan praktik Literasi.co, perkembangan dan harapan mereka tentang Literasi.co serta pengelolaan Literasi.co yang sampai saat ini dilakukan. Seluruh proses pengambilan data melalui wawancara mendalam dilakukan pada rentang waktu Januari hingga September 2016.

Analisis isi naratif dilakukan pada laman Literasi.co, baik data berupa tulisan, gambar, simbol, istilah maupun gaya bahasa serta keragaman isu yang diangkat. Hal ini dilakukan untuk mengetahui praktik-praktik Literasi.co dalam memilih dan menampilkan isu-isu yang relevan dengan tujuan-tujuan ideologis mereka. Selain itu juga untuk mendapatkan kerangka pengetahuan yang dibangun oleh Literasi.co.

Pemilihan artikel yang menjadi subjek analisis dari segi cakupan atau jumlahnya dilakukan dengan metode pembatasan rentang waktu. Sampel artikel yang dianalisis adalah artikel yang diunggah di laman Literasi.co pada periode Juli hingga Desember 2016. Di dalam rentang waktu pengumpulan antara JuliDesember 2016, terkumpul 21 tulisan yang terdiri dari berbagai isu dan kategori dalam berbagai rubrik yang tersedia di Literasi.co. Pembatasan periode analisis isi dilakukan peneliti dengan mempertimbangkan variasi isi media dan kecukupan data untuk menarik premis-premis kesimpulan dalam analisis terhadap Literasi.co.

Studiliteratur dilakukanuntuk mendapatkan beragam data dari kajian terdahulu serta konteks Indonesia dalam aspek sosial, budaya, ekonomi dan politik. Studi ini juga dilakukan untuk memperoleh data terkait keberadaan media digital dalam kegiatan aktivisme melalui media digital khususnya di Indonesia.

Analisis kualitatif secara multi-level dilakukan melalui hasil analisis isi terhadap laman Literasi.co dikaitkan dengan perolehan data di level individu, institusional maupun konteks sosial-ekonomi-politik berdasarkan hasil observasi, wawancara dan studi literatur. Interpretasi data dilakukan untuk menghasilkan penjelasan secara deskriptif dan jawaban dari tujuan penelitian.

\section{HASIL DAN PEMBAHASAN}

Pembahasan ini mengungkap hasil temuan dan analisis tentang Literasi.co terkait dengan konteks kemunculan Literasi.co, pengelolaan Literasi.co sebagai media alternatif dan kooperasi, kemampuan Literasi.co membangun ruang publik dan diskursus alternatif, serta tantangan yang dihadapi dalam menjalankan Literasi.co dan menjaga keberlanjutannya.

Terbentuknya Literasi.co tidak bisa dilepaskan dari kelembagaan Gerakan Literasi Indonesia (GLI). Organisasi yang dideklarasikan pada tanggal 17 Juni 2013 di Yogyakarta, oleh 19 orang anak muda. Menurut dokumen terkait tentang pendirian awal GLI diketahui bahwa inisiasi didirikannya GLI atas tanggapan terhadap pandangan bahwa 
kurangnya kesadaran masyarakat Indonesia terhadap berbagai penyimpangan yang terjadi terkait cita-cita kemerdekaan Republik Indonesia.

Penyimpangan tersebut diantaranya terkait aspek-aspek kedaulatan, semangat kooperasi dan solidaritas sosial yang banyak diabaikan sehingga menjauh dari tujuan cita-cita kemerdekaan yang diperjuangkan oleh pendiri bangsa ini. Itulah pandangan yang diungkapkan oleh para pendiri GLI dan menjadikan literasi sebagai jantung aktivitas mereka. Menurut pengakuan mereka seluruh sikap mental dan aktivitas GLI dilandaskan pada ideologi kedaulatan, dengan semangat kooperasi dan solidaritas sosial (www.literasi.co.id) untuk memperjuangkan cita-cita kemerdekaan sesuai dengan pemahaman mereka.

Berdasarkan landasan tersebut maka aktivitas GLI dilakukan dengan tujuan melakukan upaya untuk membangun pengetahuan dan juga kemampuan untuk melawan dogma-dogma yang mengendap di pikiran anggota masyarakat. Mereka berupaya menanamkan sikap kritis dan kesadaran masyarakat untuk memahami dan mengungkap eksploitasi manusia atas manusia.

Merujukpadaideologi, misidankegiatannya maka gerakan literasi yang dilakukan GLI berpijak pada aspek epistemologis dan aksiologis sebuah gerakan. GLI tidak saja ingin mengembangkan pengetahuan (epistemologis), akan tetapi juga menghasilkan upaya untuk melakukan perubahan atau upaya melawan hal-hal yang mereka nilai menyimpang (aksiologis). Landasan kerja itu menjadikan GLI dapat dikatakan sebagai gerakan literasi yang memiliki visi progresif dan revolusioner dalam memperjuangkan ideologi yang mereka usung.

Cita-cita GLI di masyarakat Indonesia secara strategis adalah melahirkan tatanan yang demokratis dan dinamis, di mana tafsir-tafsir kreatif atas cita-cita para pendiri bangsa dapat dilakukan. Pada posisi tersebut, GLI dan segenap anggotanya berpegang pada prinsip aksirefleksi dan harus terus-menerus melakukan kritik dan otokritik untuk memeriksa kesalahan dan kekurangannya. Hal itu diharapkan mampu mengoreksi serta mendidik kader GLI dan masyarakat sehingga konsekuensinya GLI juga harus terbuka terhadap kritik dari pihak luar.

Dalam menjalankan pekerjaannya, GLI membagi diri menjadi empat biro, yaitu 1) Biro Penelitian dan Publikasi (Litpub), 2) Biro Aksi Budaya (BAB), 3) Biro Kedaulatan Ekonomi (BKE), dan 4) Biro Pengorganisasian dan Jaringan (Organjar). Program dan aktivitas GLI, secara struktural semuanya berada di bawah keempat biro di atas. Literasi.co sendiri berada di bawah Biro Penelitian dan Publikasi (Litpub). Walaupun pelaksanaan kerja-kerja kolektif terbagi di bawah empat biro yang berbeda, akan tetapi tidak berarti kerja-kerja dilakukan secara parsial. Seluruh aktivitas yang dilakukan berbagai Biro di GLI diupayakan bersinergi dan terintegrasi satu sama lain. Salah satu contohnya adalah kelas Bengkel Menulis (BM) yang berada di bawah program Biro Organjar. Kegiatan ini pada akhirnya tetap melibatkan mereka yang berkecimpung di Literasi.co (Biro Litpub), materi-materi yang diberikan pun tak hanya beririsan, melainkan terintegrasi satu sama lain.

Berdasarkan data-data tersebut maka keberadaan Literasi.co merupakan salah satu bagian dari sebuah gerakan literasi yang lebih besar yaitu GLI. Selain itu inisiatif untuk membuat Literasi.co, berasal dari kejengahan terhadap kondisi media arus utama yang terkooptasi oleh kapitalisme. Sedangkan media-media yang berlabel ideologi tertentu juga belum sepenuhnya menjawab kebutuhan literasi (kemelekan) masyarakat terhadap isuisu publik. Hal tersebut disinyalir oleh pengelola Literasi.co, disebabkan oleh tidak hadirnya pengorganisasian massa yang mendorong kesadaran masyarakat. Oleh karena itu menjadi bagian dari gerakan yang lebih besar menjadikan Literasi.co memiliki dukungan yang cukup kuat terkait kebutuhan pengorganisasian massa.

Melalui pengorganisasian massa yang lebih baik maka isu-isu diangkat oleh Literasi. co berakar dari masyarakat. Ini akan berbeda dengan isu di media arus utama yang cenderung bersifat elitis, atau 'dari atas ke bawah,' bukan dari bawah ke atas atau tidak berasal dari masyarakat.

Konteks lain dari keberadaan Literasi. co adalah berkembangnya media alternatif yang dianggap tidak memberikan sikap yang jelas terhadap berkembangnya konglomerasi media, sebagai salah satu masalah yang coba disikapi oleh Literasi.co. Literasi.co bertujuan untuk membangun media alternatif yang terintegrasi dengan pengorganisasian massa 
untuk menghadapi kekuatan modal media arus utama dengan membangun 'kultur alternatif' yang berbeda dengan budaya media arus utama.

Pada konteks kultur alternatif maka pengelolaan media tidak merujuk pada logika ekonomi politik yang sama dengan media arus utama. Misalnya, menjadikan iklan sebagai sumber pendukung dan sistem kepemilikan yang bersifat individual atau kelompok terbatas sebagai dasar pengelolaan atau kelembagaan media. Literasi.co merintis upaya baru dengan menjadikan kepemilikan media mereka bersifat kooperatif dan distributif; kepemilikan bersifat beragam, dan terbuka pada siapa saja yang mau berkontribusi untuk Literasi.co.

Kontribusi pada Literasi.co tidak dibatasi pada uang, akan tetapi juga ide, keahlian dan kontribusi-kontribusi lain sesuai dengan kemampuan masyarakat yang ingin terlibat. Iklan tidak dijadikan tujuan atau sumber dana dalam pengelolaan media.

Dengan kata lain karakter alternatif pada Literasi.co tidak hanya pada diskursus akar rumput yang diangkat oleh media-nya akan tetapi juga terkait kelembagaan dan pengelolaan medianya. Sistem pengelolaan yang terbuka dengan berbasis pada kerjasama dan kesetaraan disebut kooperasi. Di dalam pelaksanaannya kooperasi mencakup aspek-aspek: kepemilikan media, independensi ruang redaksi, kesetaraan dalam pengelolaan serta dijadikannya partisipasi pembaca sebagai basis gerakan bagi literasi.co, termasuk dalam penggalangan dana.

Kepemilikan Literasi.co dilakukan dengan asas kebersamaan. Pemilik Literasi.co adalah seluruh anggota media kooperasi, dengan prinsip "satu orang satu suara." Setiap orang memiliki hak yang sama sebagai anggota Literasi.co. Setiap pemilik Literasi.co wajib berkontribusi dalam hal pendanaan produksi dengan jumlah yang disepakati oleh masingmasing anggota koperasi. Selain itu mereka juga harus terlibat dalam pengelolaan Literasi. co sebagai sebuah media.

Terkait khalayaknya Literasi.co juga menetapkan sistem partisipatif yang menempatkan semua yang terlibat baik sebagai produsen maupun konsumen sebagai subjek. Khalayak atau pembaca tidak diperlakukan sebagai komoditas yang akan dijual ke pengiklan untuk mendapatkan keuntungan. Pembaca akan diajak bergabung menjadi pemilik Literasi.co, melalui keanggotaannya dalam koperasi Litera seperti diungkapkan salah seorang pengelola sebagai berikut:

Untuk menjadi pemilik atau anggota Literasi.co, terlebih dahulu mesti bergabung dengan Kooperasi Litera. Kooperasi Litera merupakan kooperasi induk dari literasi.co. Setelah membayar iuran-iuran di Kooperasi Litera, maka sudah sah menjadi anggota atau pemilik Literasi.co.

Selain diajak untuk menjadi anggota koperasi dan pemilik Literasi.co pembaca mengakui bahwa dia juga dilibatkan atau dapat terlibat sebagai pemberi ide maupun penulis di Literasi.co. Dengan kata lain secara operasional Literasi.co dijalankan dengan mendorong partisipasi semua pihak, termasuk pembaca sehingga dapat memiliki posisi setara dalam sistem kelembagaan yang demokratis.

Melalui kepemilikan bersama secara kolektif dan kooperatif maka independensi redaksi Literasi.co dalam menentukan isi Literasi.co diasumsikan dapat lebih terjaga. Melalui kepemilikan yang kolektif dan koperatif maka tidak ada kelompok atau kekuasaan tertentu yang dominan dan dapat mengintervensi keputusan redaksi. Seluruh keputusan yang diambil didasarkan pada keputusan anggota redaksi Literasi.co sehingga independensi Literasi.co sebagai media terjaga secara kolektif. Sikap independen tersebut diharapkan dapat mendorong atau mewujudkan sikap kritis terhadap isi dan proses produksi media di Literasi.co.

Menurut salah seorang pengurus, berdasarkan sikap kritis yang dijadikan dasar, maka Literasi.co menetapkan semua pemilik merupakan pengawas terkait dengan kerjakerja yang dilakukan redaksi. Selain itu, sikap kritis Literasi.co juga tercermin dalam isinya yang dialamatkan pada lima hal yaitu melawan intimidasi, antagonisme realitas, dan semua bentuk dominasi akan tetapi juga mampu memanfaatkan peluang perubahan yang ada, serta terus menerus berupaya membangun masyarakat yang lebih kritis dan kooperatif. Sikap kritis redaksi juga dibangun di atas semangat aktivisme dan gerakan sosial untuk melakukan advokasi dengan mengangkat isu dari masyarakat, baik tingkat lokal, regional, maupun nasional.

Isu-isu yang dipertimbangkan dan diangkat oleh redaksi Literasi.co merupakan isu dari 
bawah atau akar rumput yang dianggap penting dan relevan, dengan permasalahan yang dialami oleh masyarakat bawah atau dimarginalkan, dan luput dari pemberitaan media arus utama. Selain itu redaksi Literasi.co juga membuka ruang bagi para partisipannya untuk melakukan kritik pada redaksi dengan memberi akses pada partisipannya untuk memberi komentar dan saran bagi redaksi.

Konsep kesetaraan terkait dengan tugas media adalah tidak boleh melupakan tanggung jawab sosialnya. Jurnalis media Literasi.co diidealkan untuk berfungsi sebagai advokat atau aktivis masyarakat, dengan misi-misi pemberdayaan masyarakat. Literasi.co melalui isu-isu yang ditampilkan, harus terus berupaya mendekatkan jarak antara media dengan masyarakat. Masyarakat adalah basis utama Literasi.co.

Masyarakat selain diajak untuk pula berpartisipasi dalam berpendapat, Literasi.co bekerjasama dengan GLI membuat pelatihan menulis dan pengayaan materi. Selain bagi masyarakat, pelatihan ini juga disediakan untuk para aktivis. Melalui kerjasama tersebut Literasi.co melakukan perubahan tidak hanya pada pengorganisasi masa akan tetapi juga pada aspek pengetahuan dan keterampilan.

Keseimbangan di antara ketiga aspek tersebut diharapkan dapat membuat Literasi. co menjadi agen perubahan yang mewarnai pengorganisasian massa dengan upaya membangun kesadaran intelektual dan keterampilan masyarakat. Hal tersebut dilakukan agar dapat mendorong masyarakat memiliki sikap kritis terhadap permasalahan sosial yang ada di sekitarnya dan mampu mengungkapkannya.

Pertemuan dalam upaya merancang pengorganisasian massa dilakukan secara teratur, seperti yang dituturkan oleh salah seorang pengelola berikut: "Pengalaman yang sudah-sudah, tim kerja melakukan pertemuan paling tidak 2 minggu sekali, atau kalau ada sesuatu di luar rutinitas, bisa bertemu sewaktuwaktu.". Melalui kegiatan advokasi, pelatihan, dan berbagai pertemuan yang diadakan maka masyarakat yang terlibat baik sebagai pembaca, penulis maupun pemilik dalam Literasi.co, menjadi memiliki ikatan dengan Literasi.co dan GLI sebagai sebuah gerakan sosial.

Kebersamaan dan ikatan di antara semua yang terlibat dalam berbagai posisi tersebut juga dibangun melalui kegiatan-kegiatan nonformal, sehingga ikatan tersebut tidak terasa hanya direkatkan secara formal, akan tetapi juga kekeluargaan. Salah seorang pengelola menuturkan: "Dari pengalaman yang sudah ada, tidak ada cara khusus untuk mengelola anggota. Hubungan dengan anggota biasanya juga dilakukan ketika kumpul bersama atau ngopi bareng."

Secara sederhana pendirian dan praktik Literasi.co sebagai media alternatif yang bersifat kooperatif dan demokratis dapat digambarkan dalam model pada gambar 1 .

Berbeda dengan media alternatif lain, yang biasanya mengidentitaskan diri dengan

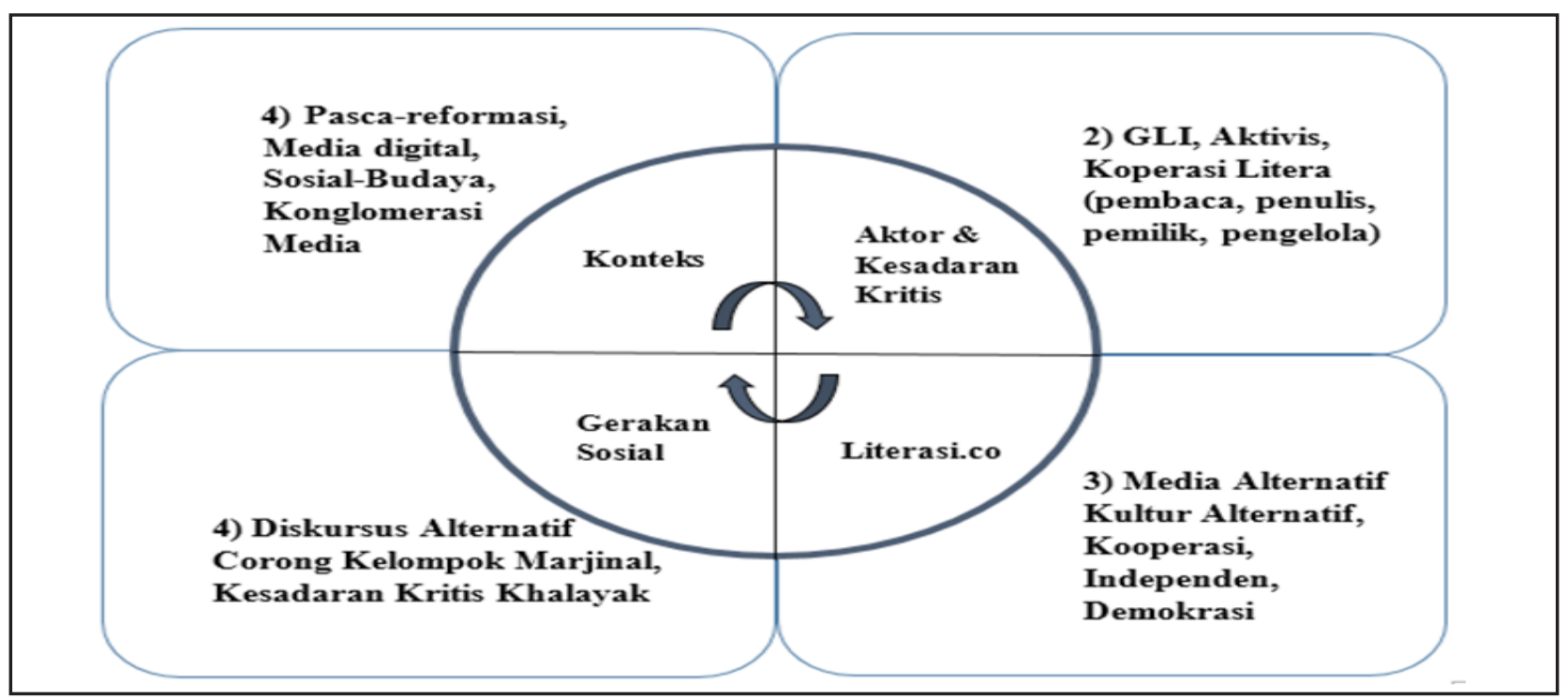

Sumber: Data Penelitian, 2016

Gambar 1 Pendirian dan praktik kelembagaan Literasi.co 
bentuk-bentuk jurnalisme baku. Literasi. co mempertimbangkan kaidah estetik dalam proses penyampaian ide sebagai bagian dari dua proses utama, yaitu agitasi dan propaganda melalui proses advokasi. Literasi.co memelihara motivasi dan semangat penciptaan dengan meneguhkan jalan kreatif dalam proses penciptaan. Isi media Literasi.com sebagai karya jurnalistik mengembangkan kemasannya dalam kategori jurnalisme dan sastra, dan sesekali di irisannya.

Pendiri yang juga seorang pengelola Literasi.co meyakini bahwa dalam upaya membongkar realitas yang termarginalkan, mengangkat dan berupaya mengubahnya diperlukan pengalaman nyata dan refleksi yang jeli. Selain itu dibutuhkan imajinasi untuk mengungkapkannya dengan rasa, secara terbuka -apa adanya-, akan tetapi menarik. Medium imajinatif tersebut dapat direpresentasikan dalam berbagai bentuk (cerpen, novel, puisi, artikel news atau views dan/atau buku teks).

Pada titik tersebut, juga ada tuntutan untuk mentransformasikan realitas sosial dan rekaman imajinasi ke dalam bentuk karya sehingga masyarakat dapat mengetahui, memahami dan merasakannya, secara lugas. Oleh karena itu Literasi.co secara elektif mengadopsi berbagai model penulisan artikel dan format tulisan, misalnya terdapat tulisan dalam bentuk cerita, kajian maupun puisi.

Terhitung sejak Juli hingga Desember 2016, terdapat 21 tulisan yang dimuat di Literasi.co. Tulisan-tulisan tersebut terdapat di berbagai rubrik yaitu: Swara Cerita, Swara Puisi, Swara Esai, Swara Kreatif, Feature, Kaji, dan Koop. Analisis yang dilakukan terhadap isi media Literasi.co dalam kurun tersebut dilakukan terhadap seluruh artikel diberbagai rubrik sehingga dapat memberi gambaran yang beragam dan penting untuk dipahami.

Swara Cerita merupakan rubrik yang dikhususkan untuk cerita-cerita pendek, dan berformat fiksional. Swara Puisi adalah rubrik puisi. Swara Esai adalah rubrik yang berisi esai-esai pendek dan topik-topiknya mencakup beragam isu publik. Swara Kreatif adalah rubrik yang berisi esai, namun analisis yang diberikan bersifat lebih kreatif jika dibandingkan dengan esai biasa. Feature merupakan rubrik untuk tulisan-tulisan jurnalisme feature. Kaji adalah rubrik yang berisi analisis terhadap fenomena sosial. Pembahasan yang terdapat dalam rubrik Kaji lebih mendalam dan subtle bila dibandingkan dengan rubrik yang lain. Rubrik Koop berisi artikel-artikel yang membahas isuisu kooperasi serta hal-hal yang memungkinkan model-model kooperasi dalam upaya mengkritisi praktik ekonomi kapitalistik yang tengah berkembang, maupun spekulasi ke depannya. Walaupun masing-masing rubrik membatasi tulisan-tulisan mereka pada bentuk-bentuk dan tema-tema tertentu, akan tetapi topik-topik yang disodorkan tetap sangat variatif, serta berelasi dan relevan dengan publik.

Dalam kurun waktu lima bulan terdapat dua tulisan yang masuk dalam kategori rubrik Swara Cerita. Dua cerita pendek berjudul "Daun-daun Di atas Arus" dan "Usman." Bila Daun-daun Di atas Arus mencoba menampilkan potret penggusuran terhadap mereka, sebagai kaum inferior, maka cerpen Usman menampilkan wujud kesederhanaan, sebagai salah satu bentuk perlawanan terhadap modernitas.

Artikel 'Daun-daun Di Atas Arus' menceritakan tentang penggusuran di sebuah desa kecil. Merujuk pada tulisan tersebut diketahui terdapat beberapa masalah terkait penggusuran ini. Pertama, tidak ada pemilik tanah di daerah itu sebelumnya, akan tapi kemudian secara mengejutkan tiba-tiba tanah itu ada pemiliknya dan mereka harus meninggalkan rumah mereka. Kedua, akan ada uang kompensasi untuk menutupi biaya pembongkaran dan relokasi yang tidak terealisasi. Di dalam cerita ini, korban-korban penggusuran ini dimetaforakan sebagai daun di atas arus. Hal itu dapat dimaknai nasib masyarakat yang rentan, terombang ambing, dan dapat larut begitu saja karena dimarginalkan dari kesadaran masyarakat. Sedangkan Usman adalah kehidupan dan kisah seorang pria bernama Usman. Orang bijak yang tinggal di rumah sederhana dan rumah bambu. Usman dapat dimaknai sebagai sosok imajinatif yang sangat diharapkan di negara ini. Cerita ini merepresentasikan kritik terhadap cara hidup mewah yang sering ditampilkan di media arus utama dan kemudian dijadikan rujukan masyarakat.

Kedua Cerita Pendek tersebut merupakan analogi dari kejadian yang dewasa ini sedang terjadi, dan berkorespondensi dengan realitas, tanpa ada kecenderungan untuk mengkhotbahi pembacanya. Kedua Cerita Pendek menjadi alat advokasi isu-isu penggusuran dan kritik 
pada gaya hidup mewah dalam bentuk karya fiksional.

Terdapat tiga puisi dalam kurun waktu lima bulan yang ditampilkan dalam rubrik Swara Puisi. Tiga puisi itu di antara lain: "Obat Kuat", "Cinta dalam Perang" dan "Romantika Hujan". Ketiga puisi tersebut menggunakan metode penyampaian yang berbeda. "Obat Kuat" menggunakan satir yang ditujukan ke pabrik semen di Rembang. "Cinta dalam Perang", menekankan aspek-aspek romantik pada masa perang, yang mengangkat ide bahwa dalam suasana konflik nilai-nilai kemanusiaan tetap hidup dalam kehidupan masyarakat. Sedangkan puisi "Romantika Hujan", lebih mengambil metode deskriptif yang mengabadikan kisah panjang tentang seorang petani di Yogyakarta bersamaan dengan hujan yang turun sebagai imajinasi kehidupan yang terbatas, dingin dan cenderung sepi.

Puisi sebagai medium digunakan dikarenakan; puisi adalah medium yang paling lugas dalam mengabstraksikan realitas, dapat membawa pembacanya untuk masuk ke dalam ruang rasa dan visual imajinatif, yang ditampilkan melalui puisi tersebut. Melalui puisi di rubrik Swara Puisi, Literasi.co tidak hanya berfungsi sebagai hiburan akan tetapi juga sebagai medium persuasi untuk membangun kesadaran pembacanya.

Terdapat satu tulisan yang masuk dalam rubrik Swara Kreatif, tulisan tersebut berjudul "Obah, Owah: Bergerak, lalu Berubah!". Obah, Owah adalah mantra ajaib dalam bahasa Indonesia mistis. Esai ini merupakan analisis menyeluruh terhadap monumen yang dibangun oleh presiden Indonesia dari waktu ke waktu. Setiap rezim memiliki simbol khusus. Di sisi lain, esai ini juga mengritik mahasiswa dan sikap lambannya terhadap rezim. Para mahasiswa telah kehilangan semangat dalam gerakan, dan menerima praktik negara begitu saja. Representasi tersebut ditujukan sebagai kritik pada mahasiswa yang melemah dalam posisi mereka sebagai agen perubahan.

Pada kurun waktu lima bulan, terdapat dua tulisan yang masuk ke dalam rubrik Feature. Format penulisan jurnalisme yang menonjolkan aspek deskriptivisme, sehingga suasana realitas dapat dibayangkan dan dirasakan oleh pembacanya. Tulisan pertama berjudul: "Rambu Duka", yang merupakan feature tentang keserakahan pabrik semen di Pati, Jawa Tengah. Feature ini meliput situasi dalam perspektif korban di Pati. Semua tercakup dalam narasi sedih sang anak kepada ibunya. Tulisan kedua berjudul Birokrat UMSU Drop Out 21 Mahasiswa karena Aksi Protes. Feature tersebut intinya membahas bentrokan antara mahasiswa Universitas Muhammadiyah Sumatera Utara (UMSU) dengan otoritas kampus yang berujung pada Keputusan (SK) Drop Out (DO) oleh Rektor terhadap 21 siswa.

Kedua feature yang ditampilkan oleh Literasi.co dapat dikategorikan sebagai bahasan tentang penindasan dan perlawanan dengan mengambil point of view yang jarang diangkat media arus utama yaitu dari sisi korban.

Secara keseluruhan terdapat enam tulisan yang berada dalam rubrik Swara Esai, merentang dari isu sastra, politik sastra hingga tindak perlawanan. Tulisan pertama merupakan esai berseri 'Tiga Halaman Belakang untuk Puisipuisi Afrizal Malna - Fasisme, Modernisme, Lirisisme (bagian I, II, III)'. Analisis panjang dan bertingkat dari puisi Afrizal Malna. Secara garis besar, esai ini berupaya menggambarkan proses kreatif Afrizal serta elemen-elemen yang mendasari dan memengaruhi Afrizal Malna dalam menyelesaikan puisinya.

Esai yang kedua masih membahas tentang sastra, berjudul 'Mengenang Sejarah Pelacuran Sastra'. Esai kedua ini berisi tentang kontestasi kekuasaan dan perdebatan seorang penyair Saut Situmorang yang diseret ke pengadilan dengan tuduhan penghinaan oleh Fatin Hamama. Fatin menyeret Saut Situmorang ke meja hijau, karena makian yang dilontarkan Saut pada saat perdebatan tentang posisi Fatin dalam politik sastra, "Sastrawan Paling Berpengaruh." Tulisan ini berupaya menunjukkan sastra di Indonesia yang dikotori oleh praktik-praktik kekerasan verbal yang kemudian menelan korban.

Esai ketiga berjudul "Pengakuan Seorang Mantan Petani". Esai yang menceritakan tentang seorang petani bersama dengan isu implisit tentang kerusakan lingkungan, penggundulan hutan dan pembersihan lahan. Esai ini mengritik lemahnya peraturan yang diberlakukan dan rendahnya kepedulian pihak berwenang dalam melindungi lingkungan.

Esai keempat, mengambil isu lingkungan dan secara spesifik membahas penolakan terhadap pabrik Semen. Esai tersebut berjudul; 'Tolak Pabrik Semen'. Esai ini berisi pendapat mengenai kasus PT. Semen Indonesia di 
Rembang sebagai bukti bahwa pemerintah lebih memprioritaskan kepentingan investor di atas kerusakan lingkungan dan masa depan bidang pertanian sebagai mata pencaharian utama masyarakat Rembang.

Menurut pengelola salah satu Rubrik yang menjadi andalan dari Literasi.co adalah rubrik Kaji. Rubrik ini berisi artikel dengan analisis yang mendalam. Selama kurun waktu 5 bulan, terdapat 5 artikel yang berada di bawah Rubrik Kaji. Rubrik Kaji kebanyakan mengambil perspektif korban dan berisi tentang persoalan penindasan yang dilakukan terhadap rakyat kecil, yang tak punya kuasa. Kuasa asimetris tersebut yang kebanyakan menjadi premis dari artikel-artikel dalam rubrik Kaji ini.

Artikel pertama berjudul "Kacang Lupa Kulit; Sesat Juga Menyesatkan.” Tulisan ini ditujukan kepada PT. Semen Indonesia yang mengambil metafora sebagai kacang tanah yang melupakan kulitnya, dalam hal ini Desa Kendeng, Jawa Tengah. Sudah tiga tahun perjuangan melawan penguasa perusahaan yang serakah, serta tuli dan mengidap kebutaan. PT. Semen Indonesia tidak lagi memperhatikan isu masyarakat dan lingkungan. Hingga saat ini pun, publik terus menentang eksistensi PT. Semen Indonesia.

Artikel kedua berjudul "Kampung Kota Bukan Rumah Slum". Artikel unggulan di Kaji ini membantah kontroversi Desa-Kota sehingga kampung di perkotaan diartikan sebagai daerah kumuh. Desa-Kota dibuat di luar rencana, atau perkampungan di kota adalah akibat dari rencana pembangunan yang timpang. Sementara itu kekumuhan merupakan ketidakmampuan pemerintah kota mengelola dan memenuhi kebutuhan penduduk khas perkampungan. Keduanya, perkampungan di kota dan daerah kumuh (slum) memiliki akar masalah yang berbeda.

Artikel ketiga mengangkat kolusi yang mengakibatkan kerusakan lingkungan dalam judul "Menolak Kongkalikong Kampus dan PLTU Cirebon." Artikel ini berisi analisis lebih lanjut mengenai kerusakan lingkungan akibat adanya "Masterplan Percepatan dan Perluasan Pembangunan Ekonomi Indonesia (MP3EI) 2011-2025." Program ini membutuhkan kebutuhan bahan bakar atau energi yang melonjak tajam. Hal ini memberi ruang bagi perusahaan asing untuk meningkatkan investasinya di industri tambang, akan tetapi penggalian berskala besar yang dilakukan dapat menyebabkan kerusakan sosial dan ekologi di Batang, Paiton, Jepara, Indramayu dan Cirebon. Akademisi yang umumnya dilibatkan untuk membuat analisis dampak lingkungan dianggap abai terhadap potensi kerusakan lingkungan.

Artikel keempat berjudul "Gusuran Bukit Duri dan Jakarta yang Kehilangan Kesempatan Menemukan atau Menteorisasikan Penanganan Banjirdi Kawasan Padat."Artikel iniberargumen tentang penggusuran yang dilakukan oleh pihak berwenang di dekat Waduk Ciliwung. Argumen yang diajukan berisi tentang deskripsi dan problem dari rasionalisasi di balik penggusuran, untuk menormalkan Sungai Ciliwung agar dapat mencegah banjir di sepanjang bantaran sungai. Penggusuran kemudian memicu konflik horizontal antara masyarakat setempat dengan Satpol PP.

Artikel kelima berjudul "Tanah Adat di Sianjur Mulamula itu pun Diklaim sebagai Tanah Pemerintah". Artikel ini terdiri dari kisah tanah adat di Sianjur Mulamula yang menyebabkan konflik. Berdasarkan deskripsi dan analisis peneliti, artikel ini memberikan rekomendasi bahwa semua pemangku kepentingan harus belajar untuk memahami sejarah, baik yang ditulis dalam literatur maupun yang diceritakan secara lisan oleh para tetua. Pemahaman yang menyeluruh, tidak akan menyeret klaim sepihak yang menyebabkan perpecahan dan pertentangan antara klan, antar desa, dan antar klan dengan pemerintah.

Rubrik yang terakhir adalah rubrik Koop yang memiliki satu tulisan berjudul "Kooperasi dan Absennya Pendidikan Berbasis Kerjasama" di bawah rubrik Koop. Esai ini mengemukakan tentang kurangnya kerjasama dalam setiap aspek kehidupan masyarakat Indonesia. Persaingan dalam dunia bisnis, eskalasi karier, pencari kerja, bahkan persaingan tertanam dalam sistem pendidikan untuk anak-anak pada usia dini. Hampir setiap aspek dalam hidup kita dikelilingi oleh daya saing. Tulisan ini mengritik apakah absennya pendidikan berbasis kerjasama sebagai landasan untuk meraih kesejahteraan kolektif?. Untuk memahami keragaman isu atau tulisan yang termuat di Literasi.co dalam kurun waktu penelitian seperti diungkapkan di atas dapat dilihat pada tabel 1 .

Pada tabel 1 terlihat kategori Rubrik berdasarkan jenis Rubrik yang terdapat di Literasi.co. Sementara kategori tema 
Tabel 1 Konten Literasi.co Juli-Desember 2016

\begin{tabular}{|c|c|c|c|}
\hline Bulan & Judul & Rubrik & Tema \\
\hline \multirow{3}{*}{ Desember 2016} & Syahadat Bumi (Ibu Bumi Dilarani) & Swara Esai & $\begin{array}{l}\text { Lingkungan-Pabrik } \\
\text { semen }\end{array}$ \\
\hline & Tolak Pabrik Semen; Laa Raiba Fiih! & Swara Esai & $\begin{array}{l}\text { Lingkungan-Pabrik } \\
\text { semen }\end{array}$ \\
\hline & Pengakuan Seorang Mantan Petani & Swara Cerita & Petani \\
\hline \multirow[t]{2}{*}{ November 2016} & Romantika Hujan & Swara Puisi & Kisah Petani \\
\hline & $\begin{array}{l}\text { Birokrat UMSU Drop Out } 21 \text { Mahasiswa } \\
\text { karena Aksi Protes }\end{array}$ & Featured & $\begin{array}{l}\text { Pembungkaman di } \\
\text { Kampus }\end{array}$ \\
\hline \multirow[t]{3}{*}{ Oktober 2016} & Cinta dalam Perang & Swara puisi & $\begin{array}{l}\text { Aspek Semiotik } \\
\text { dalam Perang }\end{array}$ \\
\hline & Kampung Kota Bukan Slum & Kaji & Penggusuran \\
\hline & $\begin{array}{l}\text { Tanah Adat di Sianjur Mulamula itu } \\
\text { pun Diklaim sebagai Tanah Pemerintah } \\
\text { (Negara) }\end{array}$ & Kaji & Tanah Adat \\
\hline \multirow[t]{4}{*}{ September 2016} & $\begin{array}{l}\text { Gusuran Bukit Duri dan Jakarta yang } \\
\text { Kehilangan Kesempatan Menemukan/ } \\
\text { Menteorisasikan Penanganan Banjir di } \\
\text { Kawasan Padat }\end{array}$ & Kaji & City Planning \\
\hline & $\begin{array}{l}\text { Menolak Kongkalikong Kampus dan } \\
\text { PLTU Cirebon }\end{array}$ & Kaji & Lingkungan-PLTU \\
\hline & Mengenang Sejarah Pelacuran & Swara Esai & Pelacuran Sastra \\
\hline & $\begin{array}{l}\text { Tiga Halaman Belakang untuk Puisi-puisi } \\
\text { Afrizal Malna — Fasisme, Modernisme, } \\
\text { Lirisisme (Bagian III-Habis)* }\end{array}$ & Swara Esai & $\begin{array}{l}\text { Kritik Sosial dalam } \\
\text { Puisi }\end{array}$ \\
\hline \multirow[t]{3}{*}{ Agustus 2016} & $\begin{array}{l}\text { Tiga Halaman Belakang untuk Puisi-puisi } \\
\text { Afrizal Malna — Fasisme, Modernisme, } \\
\text { Lirisisme (Bagian II)* }\end{array}$ & Swara Esai & $\begin{array}{l}\text { Kritik Sosial dalam } \\
\text { Puisi }\end{array}$ \\
\hline & $\begin{array}{l}\text { Tiga Halaman Belakang untuk Puisi-puisi } \\
\text { Afrizal Malna — Fasisme, Modernisme, } \\
\text { Lirisisme (bagian I)* }\end{array}$ & Swara Esai & $\begin{array}{l}\text { Kritik Sosial dalam } \\
\text { Puisi }\end{array}$ \\
\hline & $\begin{array}{l}\text { Ko-operasi dan Absennya Pendidikan } \\
\text { Berbasis Kerjasama }\end{array}$ & Koop & Pendidikan \\
\hline \multirow{6}{*}{ Juli 2016} & Rambu Duka & Swara Cerita & $\begin{array}{l}\text { Keserakahan } \\
\text { pabrik semen }\end{array}$ \\
\hline & Usman & Swara Cerita & $\begin{array}{l}\text { Sosok bijak yang } \\
\text { mencerminkan } \\
\text { perlawanan }\end{array}$ \\
\hline & Obat Kuat & Swara Puisi & $\begin{array}{l}\text { Satir berisi kritik } \\
\text { pada pabrik semen }\end{array}$ \\
\hline & Obah, Owah: Bergerak, lalu Berubah! & $\begin{array}{l}\text { Swara } \\
\text { Kreatif }\end{array}$ & $\begin{array}{l}\text { Kritik sosial pada } \\
\text { mahasiswa }\end{array}$ \\
\hline & $\begin{array}{l}\text { Kacang Lupa Kulit; Sesat Juga } \\
\text { Menyesatkan. }\end{array}$ & Kaji & Lingkungan \\
\hline & Daun-daun Di Atas Arus & Swara Cerita & Penggusuran \\
\hline
\end{tabular}

Sumber: Literasi.co, 2016 
ditetapkan berdasarkan analisis peneliti terhadap representasi fokus, subjek dan gaya penyampaian dari deskripsi isi media yang dianalisis baik berdasarkan analisis terhadap isi tertulis dari judul maupun isi berita serta simbol atau gambar yang digunakan.

Berdasarkan analisis terhadap isi media yang terdapat di Literasi.co secara keseluruhan narasi isi media tersebut bersifat advokatif. Narasi yang diangkat digunakan untuk mendampingi dan menyuarakan isu-isu publik seperti yang terlihat pada artikel 'Daun-daun Di Atas Arus' artikel 'Rambu Duka' atau puisi 'Obat Kuat'.

Isi media juga mengangkat konflik terkait tanah adat dalam artikel "Tanah Adat di Sianjur Mulamula itu pun Diklaim sebagai Tanah Pemerintah (Negara)", kasus diberhentikannya mahasiswa karena melakukan protes di kampusnya dalam artikel "Birokrat UMSU Drop Out 21 Mahasiswa karena Aksi Protes".

Sebagian besar isu-isu publik tersebut diberitakan dengan menggunakan perspektif korban, perspektif yang jarang muncul di media arus utama. Terdapat jarak antara media arus utama dengan realitas kehidupan masyarakat yang jadi korban dari berbagai kasus penggusuran, penindasan, atau pembungkaman.

BerdasarkanisuyangdiangkatmakaLiterasi. co pada dasarnya telah berhasil membangun ruang publik terkait dengan beragam wacana. Akan tetapi untuk mewujudkan harapan tentang dibutuhkannya media alternatif sebagai sebuah bentuk media ideal yang dapat dikembangkan para aktivis atau masyarakat sipil Literasi.co masih memiliki banyak tantangan.

Walaupun Literasi.co sebagai media kooperasi membuka peluang keanggotaan bagi seluruh rakyat Indonesia akan tetapi kemampuannya melibatkan masyarakat sipil melalui pengorganisasian massa masih terbatas. Oleh karena tantangan pertama yang dihadapi dalam pengelolaan Literasi.co adalah keterbatasan partisipan yang dapat aktif terlibat dalam pengelolaan. Hal ini menjadi tantangan pertama karena berimbas pada konsistensi terbitan dan proses memperbarui isi Literasi.co sebagai media alternatif yang harus mengangkat beragam isu yang dimarginalkan media arus utama.

Literasi.co juga menjadi sebuah bentuk koreksi terhadap media alternatif yang pada awalnya membuka kanal partisipasi masyarakat melalui konsep jurnalisme warga yang diselewengkan dengan menjadikan warga bagian dari sistem produksi media arus utama. Masyarakat pada akhirnya hanya dilibatkan dalam proses pencarian dan produksi pesan dan tidak memberi peluang partisipasi masyarakat dalam sistem kepemilikan dan sistem kontrol isi media, atau dengan kata lain partisipasi justru digunakan sebagai alat akumulasi kapital dan masyarakat kembali menjadi objek (Vebrynda, Maryani, \& Abdullah, 2017).

Melalui platform media digital, Literasi.co sebagai media online memiliki sistem produksi yang lebih sederhana dan dapat diakses secara lebih luas. Selain itu sebagai media online juga memungkinkan interaksi yang lebih aktif dan partisipatif. Melalui berbagai isu yang berangkat dari bawah, Literasi.co berhasil menawarkan diskursus alternatif yang menyuarakan suara akar rumput dan mencerminkan kepentingan akar rumput. Dengan kata lain Literasi.co dapat membangun ruang publik bagi kalangan masyarakat bawah yang tidak mendapat ruang dalam sistem media arus utama.

Walaupun mendapat kemudahan terkait dengan sistem produksi dan jangkauan yang lebih luas melalui media online, Literasi.co masih memiliki beberapa tantangan. Gerakan sosial yang dijalankan Literasi.co sebagai bagian dari Gerakan Literasi Indonesia tidak hanya untuk memberi ruang akan tetapi harus mampu melakukan transformasi nilai-nilai atau ideologi yang diusungnya. Dominasi media arus utama yang menyebarluaskan nilai-nilai yang berbeda atau bertentangan dan secara masif dan intensif. Tantangan ini menjadi suatu ancaman tersendiri bagi kelangsungan gerakan sosial yang diperjuangkan. Melalui Literasi.co sebagai bagian dari sebuah gerakan sosial maka diharapkan dapat berkontribusi signifikan untuk melakukan perubahan bagi kepentingan akar rumput.

Literasi.co saat ini masih dihadapkan pada kurangnya partisipasi masyarakat dalam pengelolaan baik dalam sistem produksi maupun distribusi Literasi.co. Selain itu Literasi juga memiliki masalah untuk mengubah perhatian dan pola atau kebiasaan masyarakat dalam mengonsumsi media. Masyarakat yang telah terbiasa mengonsumsi berbagai media arus utama, harus direbut perhatiannya. Salah satu upaya yang dilakukan adalah dengan 
menjadikan beragam wacana yang diangkat Literasi.co sebagai pembicaraan umum. Upaya tersebut tidak mudah karena Literasi.co harus berhadapan dengan media arus utama yang sudah mapan dan terintegrasi serta didukung dana luar biasa besar.

Di dalam kondisi tersebut Literasi.co tidak dapat bergerak sendiri akan tetapi membutuhkan kontribusi dan kerja-kerja kolektif dari banyak elemen, baik dari kelas pekerja maupun akademisi. Perubahan sosial di masyarakat tidak bisa hanya dilakukan oleh satu elemen atau satu institusi akan tetapi semua elemen masyarakat sipil dari berbagai institusi harus bersinergi dengan aktivis dan kelompok masyarakat yang dimarginalkan serta tertindas, dalam gerakan sosial yang berkelanjutan.

\section{SIMPULAN}

Literasi.co dibangun pasca reformasi saat regulasi yang mengekang pers atau media dicabut. Selain itu berkembang pula kesadaran adanya marginalisasi isu dan kepentingan kalangan bawah atau akar rumput oleh media arus utama yang semakin komersial dan membangun konglomerasi media.

Hadirnya Literasi.co juga terkait dengan adanya sejumlah aktor yang memiliki kesadaran kritis tentang terjadinya penyimpangan citacita kemerdekaan bangsa Indonesia. Kesadaran tersebut melahirkan organisasi yang bernama Gerakan Literasi Indonesia (GLI). GLI menyadari pentingnya keberadaan media untuk membangkitkan kesadaran kritis masyarakat sehingga membentuk Literasi.co sebagai media alternatif di bawah Biro Penelitian dan Publikasi (LitPub).

Walaupun telah muncul beberapa media alternatif, akan tetapi belum banyak yang menjalankan proses partisipatif dalam bentuk institusi, pendanaan, dan pengelolaan isi media. Literasi.co mengisi kekosongan tersebut dengan membentuk model kepemilikan dan pengelolaan media secara bersama atau kooperasi. Kepemilikan media secara bersama dijalankan melalui keanggotaan masyarakat dalam koperasi Litera. Artinya kepemilikan Literasi.co adalah kepemilikan bersama para anggota koperasi Litera yang terdiri dari para pendiri dan anggota masyarakat yang menjadi anggota koperasi.

Keanggotaan koperasi Litera ditawarkan secara terbuka kepada masyarakat atau para pembaca Literasi.co. Kepemilikan media secara bersama ini menjadi dasar Literasi. co membangun kerja keredaksian yang independen dan bersinergi dengan semangat solidaritas sosial serta aktivisme sosial akar rumput yang juga independen. Selain itu model ini menempatkan masyarakat sebagai subjek bukan sekedar sasaran atau objek. Melalui platform media digital, Literasi.co memiliki sistem produksi yang lebih sederhana dan dapat diakses lebih luas serta memungkinkan Literasi. co membangun interaksi yang lebih partisipatif.

Sistem pengelolaan yang melibatkan masyarakat merupakan upaya Literasi.co untuk membuka ruang bagi masyarakat atau kelompok yang dimarginalkan dalam sistem produksi dan distribusi media arus utama. Literasi.co juga menjadi corong kepentingan masyarakat bawah atau yang tertindas dengan mengangkat berbagai isu dari isu agraria, tata ruang kota, kebudayaan, hingga sastra. Literasi.co tidak saja mengangkat isu yang dimarginalkan media arus utama akan tetapi juga mengangkat perspektif yang berbeda dalam setiap kasus yaitu perspektif korban.

Literasi.co berhasil menawarkan diskursus alternatif dari dan untuk masyarakat sipil, serta menyuarakan kepentingan akar rumput pada publik yang lebih luas. Selain itu, Literasi. co sebagai media alternatif dapat mendorong terbangunnya kesadaran kritis masyarakat. Melalui Literasi.co masyarakat memahami beragam isu atau masalah mereka dan didorong untuk terlibat aktif dalam upaya mencari solusi maupun memperjuangkan prosesnya.

Selain dapat menjalankan perannya sebagai media alternatif yang dapat mendorong terjadinya perubahan, Literasi.co juga memiliki beberapa tantangan. Beberapa tantangan yang teridentifikasi; praktek redaksi yang terbatas sehingga terjadi inkonsistensi penerbitan, kurang optimalnya pengorganisasian massa untuk meningkatkan partisipasi masyarakat, dan tantangan untuk mengubah masyarakat yang terbiasa mengonsumsi media arus utama.

Sebagai sebuah gerakan sosial Literasi. co tidak dapat bergerak sendiri, model kerja Literasi.co membutuhkan kontribusi dari banyak elemen, mulai dari masyarakat kalangan bawah, aktivis, jurnalis maupun akademisi. Jika tidak, maka keberlanjutan Literasi.co akan sulit dipertahankan dan Literasi.co hanya akan menjadi bagian dari sejarah gerakan sosial 
melalui media digital di Indonesia.

KritikterhadapLiterasi.coadalahkurangnya kemampuan mengembangkan jaringan kerja dengan kelompok-kelompok atau lembaga yang berbeda akan tetapi memiliki idelogi yang sama. Penelitian ini merekomendasikan agar Literasi.co dapat bekerja sama dengan Perguruan Tinggi dan Lembaga-lembaga lain yang bersifat independen.

Perguruan tinggi yang mengelola program di bidang Komunikasi dan Media berpotensi menjadi mitra Literasi.co. Partisipasi mahasiswa dapat dikembangkan dalam proses produksi maupun untuk mengangkat keberadaan Literasi. co di dalam wacana masyarakat. Aktivitas media digital mahasiswa yang relatif tinggi akan sangat signifikan dalam upaya tersebut. Lembaga-lembaga independen misalnya seperti Komisi Pemberantasan Korupsi (KPK) dan Komisi Anti Kekerasan terhadap Perempuan (Komnas Perempuan), dapat dijadikan mitra sebagai sumber informasi dan dukungan untuk mengangkat isu-isu terkait penyelewengan maupun penindasan pada beragam kelompok atau masyarakat.

Sebagai media alternatif yang independen dan menggunakan platform media digital peluang Literasi.co untuk memperluas jaringan sangat potensial dan terbuka.

\section{DAFTAR PUSTAKA}

Atton, C. (2001). Alternative media. London: Sage.

Babe, R. E. (2009). Cultural studies and political economy. Plymouth: lexington books. Diakses dari https://moodle.lse. ac.uk/pluginfile.php/800229/mod_page/ content/9/Cultural studies and political economy Toward a new integration.pdf

Crawshaw, S., \& Jackson, J. (2015). Tindakantindakan kecil perlawanan. Yogyakarta: INSISTPress.

Fuchs, C. (2008). Internet and society: Social theory in the information age (Vol. 136). New York: Routledge.

Fuchs, C. (2010). Alternative media as critical media. European Journal of Social Theory, 13(2), 173-192. https://doi. org/10.1177/1368431010362294.

Jurriens, E. (2003). Radio komunitas di indonesia: "new brechtian theatre" di era reformasi? Antropologi Indonesia, 72,
116-130.

Kenix, L. J. (2011). The future of alternative media? Observatorio, 5(1), 187-214. https://doi.org/10.1007/PL00011397.

Lim, M. (2012). The league of thirteen: media concentration in indonesia. Diakses dari http://www.public.asu.edu/ mlim4/files/ Lim_IndoMediaOwnership_2012.pdf.

Lim, M. (2013). Many clicks but little sticks: social media activism in indonesia. Journal of Contemporary Asia, 43(4), 636-657. https://doi.org/10.1080/00472336.2013.76 9386.

Lin, Z. (2016). Traditional media, social media, and alternative media in hong kong's umbrella movement. Asian Politics and Policy, 8(2), 365-372. https://doi. org/10.1111/aspp.12258.

Mahaswari, M. (2012). Jalin merapi: penggunaan media baru dan gerakan sosial penanggulangan bencana. Jurnal Komunikasi Indonesia, I(2 Oktober 2012).

Maryani, E. (2011). Media dan perubahan sosial: suara perlawanan melalui radio komunitas. Bandung: Rosda Karya.

Maryani, E., \& Adiprasetio, J. (2017). Magdalene.Co sebagai media advokasi perempuan. Jurnal Ilmu Komunikasi, (23), 111-124.

Nugraha, S., \& Santana, S. (2009). Bingkai media alternatif jakartabeat.net tentang kondisi musik indie di indonesia. Prosiding Jurnalistik (pp. 15-22).

Nugroho, Y., Putri, D. A., \& Laksmi, S. (2012). Mapping the landscape of the media industry in contemporary Indonesia. Ford Foundation, (March), 4. https://doi. org/10.2304/pfie.2007.5.2.264.

Sandoval, M., \& Fuchs, C. (2010). Towards a critical theory of alternative media. Telematics and Informatics, 27(2), 141-150. https://doi.org/10.1016/j.tele.2009.06.011.

Senova, A. (2016). Literasi media sebagai strategi komunikasi tim sukses relawan pemenangan pemilihan presiden jokowi jk di bandung. Jurnal Kajian Komunikasi, 4(2), 142-153. https://doi.org/https://doi. org/10.24198/jkk.v4i2.

Setiap Hari Terbit Lima Media Massa Baru Pasca-Reformasi. (2008). Retrieved from https://www.antaranews.com/berita/93625/ setiap-hari-terbit-lima-media-massa-baru- 
pasca-reformasi.

Syahputra, I. (2013). Rezim media: pergulatan demokrasi, jurnalisme, dan infotainment dalam industri televisi. Yogyakarta: Gramedia.

Tracy, S. J. (2013). Qualitative research methods: collecting evidence, crafting analysis, communicating impact. West Sussex: Wiley-Blackwell.

Vebrynda, R., Maryani, E., \& Abdullah, A. (2017). Konvergensi dalam program net citizen. Jurnal Kajian Komunikasi, 5(1), 53-68.

Wahl-Jorgensen, K. \& Hanitzsch, T. (2008). Handbook of journalism studies. New York: Routledge.

Yudha, R. P. (2017). Tantangan literasi era media digital. Jurnal Interaksi, 6(1).

Yusuf, I. A. (2011). Media lokal dalam konstelasi komunikasi politik di daerah. Jurnal Ilmu Sosial Dan Ilmu Politik, 14(3), 298. https:// doi.org/10.22146/JSP.10930. 